\title{
Indian Writing in the English-speaking World
}

\author{
Dauike Rejaram \\ Thangavelu Engineering College, Department of English, Karapakkam, Chennai, India
}

\begin{abstract}
Indian English Literature is an honest enterprise to demonstrate the ever-rare gems of Indian Writing in English. From being a singular and exceptional, rather gradual native flare - up of geniuses, Indian Writing has turned out to be a new form of Indian culture and voice in which India converses regularly. Indian Writers - poets, novelists, essayists, and dramatists have been making momentous and considerable contributions to world literature since pre - Independence era, the past few years have witnessed a gigantic prospering and thriving of Indian English Writing in the global market. Indian English Literature has attained an independent status in the realm of world Literature. Wide ranges of themes are dealt with in Indian Writing in English. While this literature continues to reflect Indian culture, tradition, social values and even Indian history through the depiction of life in India and Indians living elsewhere, recent Indian English fiction has been trying to give expression to the Indian experience of the modern predicaments. There are critics and commentators in England and America who appreciate Indian English novels. Prof. M. K. Naik remarks, "One of the most notable gifts of English education to India is prose fiction for though India was probably a fountain head of story-telling, the novel as we know today was an importation from the west".
\end{abstract}

Keywords: literature, author, industrialization, men, fiction, critics, award, personality

\section{Introduction}

Indian writing in English has gained worldwide acceptance and recognition. The emergence of new talent has brought in its wake newer themes, ideas and forms of writing. Independence brought in its wake partition, a traumatic experience, the aftermath of which continues to haunt us even today. Independent India strove to build economy. The Indian government decided to go in for industrialization. This brought about a great change as agricultural India gave way to industrial India. Along with industrial development, there is a host of new problems. The writers dwelt on human relationships. Our lives revolve around them in some form or the other, relationship cannot grow from nothing. They develop through association and require a long gestation period It can be proudly said that Indian writers especially whom William Walsh called The Big Three R.K Narayan, Raja Rao and Mulk Raj Anand have blazed a new trail in Indian Writing. In their long writing career, they reinterpreted Indian ethos, each in his own way, taking up the lives of the disadvantaged and marginalized section effectively.

\section{Objective}

The goal and purpose of this paper is to demonstrate the significance of Indian writing in our day-to-day life as well as discuss about the evolution of Indian literature and its prominent authors. This paper is an attempt to summarize the growth of English literature in the history of India, growth of industrialization and cultural diversities

\section{Evolution}

The writers dwelt on human relationships. Our lives revolve around them in some form or the other, relationship cannot grow from nothing. They develop through association and require a long gestation period It can be proudly said that Indian writers especially whom William Walsh called The Big Three R.K Narayan, Raja Rao and Mulk Raj Anand have blazed a new trail in Indian Writing. In their long writing career they reinterpreted Indian ethos, each in his own way, taking up the lives of the disadvantaged and marginalized section effectively.

After 1950, however Indian English novelist's interest moved from the public to the private sphere. They began to delineate in their work the individual's quest for the self in all its varied and complex forms along with his problems and crises. Most of them in their eagerness to find new themes renounced the larger world in favour of the inner man and engaged themselves in a search for the essence of human beings. Novelists like Anita Desai, Arun Joshi and Nayantara Sahgal have altered the face of Indian English novel and their works contain seeds of future development. While the Big Three are still alive, the novelists of the second and third generations keep on bringing out remarkable novels from time to time.

From the 1960s onwards Indian Writing in English witnessed great change Writers like Kamala Das, Nissim Ezekiel, Keki Daruwalla and others began to write in a frank and candid manner. The writer noticed a gradual erosion of social values and this is reflected in literature of his period No writers could stand in isolation and watch the changes taking place in India. The writings reflect the yearning, frustrations and desperate anguish of the people. Independence had infused enthusiasm in the people. As the euphoria of independence dissipated, reality with its myriad problems loomed large. Indian English novel reflected this change.

The defiant, individualistic protagonist arouses our interest and stirs our imagination. Sometimes, some of these novels disturbed established pattern of thought and shocked our sensibilities. In the growth and development of Indian English novel, 1980s occupy the most significant position. During the last one and half decade some very promising novelists have published their first work which speaks eloquently about the originality and unperfected inventiveness of these novelists along with their capability of 
doing away with all apishness and complexes constraints which the earlier novelists had to suffer. It is in this period that Indian

English novelists and novels earned unheard of distinction in the western academic world. It is again during that period highly talented novelists produced what Antony Burges would call some great unexpected masterpieces which burn up the whole world by its meritorious achievements.

Notwithstanding numerous challenges and problems, Indian English novelists have been doing well. Their works display a maturity in a choice and treatment of themes, plots constructions, delineation of characters and logistic improvisation. It is clear from A Suitable Boy, The God of Small Things and The Inheritance of Loss and some other works, Indian English novel now enjoys an outstanding position and has carved out a place for itself in the broader context of the World Literature.

After the 1980s, one finds a definite change in the expression of the Indian writing in English. They have begun to use language in a very effective way. Be it Shobha De, Upamanya Chatterjee, Mukul Kesavan, Arundhanthi Roy or Imitaz Dhakar, one notice how consumerism has taken a firm grip on the lifestyles of urban Indians. Material pursuits reign supreme and this was reflected in the writings of novelists. Their writings evoke a pictorial image of the Indian society and reflect the cultural diversity of India. Writing depicted the fragmented, marginalized and racially discriminated people.

The modern Indian English writers began to question the imposition of social practices which were arbitrary. The different culture of India highlights the cultural 'difference of the people. There were elite cultures and even today they continue to be so. New writers began experimenting with the form and literary works associated with post-colonial experience of migration, identity crisis and Diasporas began to be written Undoubtedly, Indian English Literature has earned widespread reputation both in India and abroad. We can look forward to more Indian writing which will enlighten us. The origin of Indian English fiction dates back to June 6, 1865 with the publication of Kaliash Chandra Dutt's A Journey of the Year (1945) which appeared in The Calcutta Gazette on 6t June 1853.

In this literary fantasy the author narrates the story of an imaginary unsuccessful revolt against the British rule a hundred year later. In the same vein is Shoshee Chunder Dutt Republic of Orissa. Neither of these two tales can strictly be called political fiction because the motif of political independence in them is more in the nature of a peg to hang a novelistic fantasy on than a strong nationalist urge, but they do show a certain awareness of the pressure of the times. The first Indian English novels are proper, Bankim Chandra Chatterjee, Rajmohan's Wife shows this awareness being applied to the contemporary social scene.

Ever since the publication of this novel, Indian novel in English has grown by leaps and bounds in respect of the bulk, variety and maturity. An idea of the nature and extent of their growth and development and potential of this literary form in India can be had by placing the early novels written by Indian beside some recent works. Most early novels in English by Indians were invariably imitative and immature. Quite a few of them turned out to be only poor relation of the novels written by the Victorian novels like B.Rajan Iyer's Vasudeve Shashiri (1905) Balkrishna's The Love of Kusum(1910), A. Madhaviah Thillai Govindan (1912) and Sir Jogendra Singh's Nareen (1915) are all very feeble as work of literature. As Srinivasa Iyenger point out, these early novels have for us today no more than an antiquarian or historical interest. While pointing out the real problems and difficulties facing the Indian novels written in vernacular are more enterprising, they are richer in content and wider in range. The early novelist's choice of them was stereotypical and their grasp over the language uncertain. The literary scene in the beginning of the last century was thus dismal, but the fact remains that really pioneering efforts were made by some Indian novelists to exploit the resources and potential of a fluid form of self expression. The emergence of the Big Three Mulk Raj Anand, Raja Rao and R. K. Narayan on the literary firmament brought new hopes about the creative activity in the form of fiction. R. K. Narayan was accorded an honorary membership of the American Academy and Institute of arts and Letters in 1981. William Walsh maintains that it was in 1930s that the Indians began what now turned out to be their very substantial contribution to the novel in English.

The development of Indian English novel seems to follow certain definite pattern and consists of well-defined stages. Although the earliest novels were not of much artistic worth, they struggled to carve out a place for them. The gradual progression from the imitative stage to realistic to psychological to experimental is not difficult to trace. After World War I Indian English novels became more realistic and less idealized. The novelistic mode introduced deliberate efforts to depict distress of the downtrodden classes, portraying India as she really was the novels between the World Wars were primarily concerned with the contemporary social milieu and were greatly influenced by the Gandhian ethos. It is in this phase that we came across excellent novels for the first time, as is evident from Mulk Raj Anand's Untouchable (1935), R.K. Narayan's Swami and Friends (1935), Raja Rao's Kanthapura (1930) They proved to be highly valuable to the nationalists and revolutionaries as convenient and effective means popularizing and disseminating their cause. On account of the surging nationalistic feelings the content of the novel underwent profound change and it had to cater to demands of Zeitgeist when the scene shifted to the contemporary battles and agitations.

After 1959, however, Indian English novelist's interest moved from the public to the private share. They began to delineate in their works the individual's quest for all varied and complex forms along with his problems and crises. Most of them in their eagerness renounced the larger world in favour of the inner man and engaged themselves in a search for the essence of human beings, novelist' like Anita Desai, Arun Joshi and Nayantara Sahgal have altered the face of Indian English novel and their works contain seeds of future development. While the Big Three were still creatively alive 
for a long time the novelist's of the second and third generations kept on bringing out remarkable novels from time to time.

In the growth and development of Indian English novel, 1980s occupy the most significant position, During the last one and half decades some very promising novelist have published their first work which speaks eloquently about the originality and unperfected inventiveness of these novelists along with their capability of doing away with all apishness and complexes and constraints which the earlier novelists had to suffer from. It is this period that Indian English novelists and novels earned unheard of distinction in the western academic world. It is again during that period highly talented novelists produced what Antony Burges would call some great-unexpected masterpieces, which burn up the whole world by its meritorious achievements notwithstanding numerous challenges, and problems, Indian English novelists have been doing well. Their works display a maturity in a choice and treatment of themes, plot construction, delineation of characters and logistic improvisation. As is clear from A Suitable Boy (1993), The God of Small Things (1997) and The Inheritance of Loss (2006) and other works, Indian English novel now enjoys an outstanding position and has carved out a place for itself in border context of the World Literature.

Despite all foreboding, misgivings, problem and challenges, Indian English novel has already proved its worth and possibilities. In 1993, Salman Rushdie's Midnight Children was adjudged the Booker of Bookers the best novel to have won the Booker Prize in its twenty-five years. There are also brilliant novels by Amitav Ghosh and now increasingly talked about Kiran Desai, Amit Chaudhary and a stunning piece by Abraham Verghese. Arundhati Roy's debut novel The God of Small Things has been awarded the Booker Prize for 1997. This prize for 2006 has been given to Kiran Desai for her second novel The Inheritance of Loss. Aravind Adiga's The White Tiger has portrayed a trenchant picture of contemporary India and won international acclaim.

All these novels with earlier masterpieces have brought the new Indian English novel into sharp focus. The rich harvest of talent in Indian English fiction has already kindled hope of better productions. Indian Novel in English from its humble beginning with Bankim Chandra Chatterjee's Rajmohan's Wife in 1864. Shashi Deshpande was born in the year of 1938 in Karnataka. Her father Sriranga was an eminent Kannada dramatist and writer. She obtained her early schooling at a protestant mission school in Karnataka. Since childhood he used to be fond of English literature and used to read a number of English books. Particularly she preferred the work of Jane Austen. Later she studied Economics in Bombay and graduated in Law from Bangalore. After that she acquired an M.A in English Literature.

In 1978 her first anthology of short stories used to be published. Two years after in 1980 her first novel The Dark Holds No Terror was published. In 1990 she got Sahitya Akademi Award for the novel That Long Silence. In 1996 her well-known novel A Matter of Time was published in which she unfolds the different experiences of women in India. She additionally penned some children's books. The Binding Vine was published in 2002. Her novels are based on women lives and their problems particularly in the Indian context. For this cause, she has been labelled feminist. She explored the realities behind the silence of women. She raised her voice in opposition against torture of women and created mass awareness in this matter through her writings. Her books are translated into several Indian languages. Age in life and literature for centuries.

\section{Prominent Authors}

A. Shashi Deshpande published her first collection of short stories in 1978, and her first novel, The Dark Holds No Terror, in 1980. She received the Sahitya Akademi Award for the novel That Long Silence in 1990 and the Padma Shri award in 2009. Shashi Deshpande has written four children books, a number of short stories, and nine novels, except quite a few perceptive essays, now reachable in a collection entitled Writing from the Margin and Other Essays. Shashi Deshpande reveals an exciting photo of an ordinary middle category educated woman. The protagonist Jaya lives with her husband Mohan and two teens Rahul and Rati The story entirely revolves Java, her married lifestyles and her position as a dutiful wife and affectionate mother carefully being dutiful to her in-laws to Aai, Ajji, Kaka and her relatives. It gives simple captivating scenes solely expressed by the author. The travails of life in a conservative household are well established. According to the writer husbands take for granted their wives emotions likes and dislikes to be same like theirs and right here creator stresses, punctuates and reciprocates these emotions which are expressed in vivid detail like that of love making and relationship with children. She ponders at some point of the story of her functional clarity her life and thinks is she leading a life for her or for any person else searching her identity as an individual. Her feelings are getting subdued. As one reads one question one's personal identity Married ladies might discover some instances similar in their everyday lives. Author has performed an accurate job in and expressing intimacy and Sexual feeling in this natural tone.

B. Anita Mazumdar Desai was on born June 24, 1937. She is an Indian novelist and Emeritus John E.Burchard Professor of Humanities at the Massachusetts Institute of Technology. She has been shortlisted for the Booker Prize three times, awarded the Sahitya Akademi Award, in 1978 for her novel, Fire on the Mountain, via the Sahitya Akademi, India's National Academy of Letters. Born as Anita Mazumdar to a German mother, Toni Nime, a Bengali businessman, D.N.Mazumdar in Mussoorie, India. She grew up speaking German at home and Bengali, Urdu, Hindi and English in the backyard of the house. She first learned to read and write in English and as a result, it grew to be her literary language (Agarwal 19). Despite German being her first language she did not go to Germany until later in her life. She used to be a scholar at Queen Mary's higher secondary school in Delhi and acquired her B.A. in English Literature in 1957 from the Miranda House of the University of Delhi. The following year she married Ashvin Desai, the 
director of a software company and creator of the book, Between Eternities: Ideas on Life and the Cosmos. They have four children Booker Prize- winning novelist Kiran Desai. Her young children were taken to Thul near Alibagh for weekends, where Desai set her novel The Village by the Sea.

C. Kiran Desai born Third September 1971 is an Indian author who is a citizen of India and a permanent resident of the United States. Her novel The Inheritance of Loss gained the 2006 Man Booker Prize and the National Book Critics Circle Fiction Award. She is the daughter of the leading author Anita Desai and the partner of Orhan Pamuk. Kiran Desai used to live in New Delhi, India, and continued there until she was ten. She left India at fourteen and she and her mother then lived in England for a year, and then moved to the United States, where she studied innovative writing at Bennington College, Hollins University, and Columbia University In January 2010, the Nobel Laureate Orhan Pamuk acknowledged that he was once in a relationship with Desai. Ferit Orhan Pamuk, commonly recognized actually as Orhan Pamuk, is a Turkish novelist. He is additionally the Robert Yik Fong Tanm Professor in the Humanities at Columbia University, where he teaches comparative literature and writing One of Turkey's most prominent novelists he teaches comparative literature and writing.One of turkey's most prominent novelists Orhan Pamuk's works have sold over seven million books in more than fifty languages, making him the country's best-selling writer. Pamuk is the recipient of numerous literary awards, including the first Nobel Prize to be awarded to a Turkish citizen. Kiran Desai's first novel, Hullabaloo in the Guava Orchard, was published in 1998 and received accolades from such notable figures as Salman Rushdie. It went on to bag the Betty Trask Award given by the society of Authors for the best new novels by citizens of commonwealth of Nation under the age of thirty five. Her second book, The Inheritance of Loss (2009) has been widely praised by critics throughout Asia, Europe and the United states and won the 2006 Man Booker prize as well as the 2006 National Critics Circle Fiction Award.In September 2007 she was a guest on private passions, the biographical music discussion programme hosted by Michael Berkeley on BBC Radio three. In May 2007 she was the featured author at the inaugural Asia House Festival of Asian Literature. The novel shows the interior clash in India between the Muslim factions and the Buddhist groups whilst at the same time displaying a conflict between previous and present. The Inheritance of Loss (2006) is the second novel of Kiran Desai. It got the Man Booker prize, in the same year. It also claimed the Vodafone Crossword Book Award in 2006 and Book Critics circle Fiction Award in 2007. It was published Seven years after Hullafaloo in the Guava Orchard. The major themes are migration and the conflict of the two different worlds as well a past and present. The story is mainly centred on the characters of Biju and Sai. Biju is the illegal Indian Immigrant in the USA and Sai lives in Darjeeling. His attempt of Biju in search of a new life and the life of Sai, an anglicized girl living with her grandfather are portrayed.
D. Kamala Das was born in Punnayurkulam, Thirissur District in Kerala, on March thirty first, 1934, to V.M. Nair, a former managing editor of the widely- circulated Malayalam newspaper Mathrubhumi, and Nalappatt Balamani Amma, a noted Malayali poetess She spent her childhood between Calcutta, where her father was employed as a senior officer in the Walford Transport Company that bought Bentley and Rolls Royce automobiles, and the Nalappatt ancestral home in Punnayurkulam. Like her mother, Kamala Das additionally excelled in writing. Her love of poetry started out at an early age under the influence on of her great uncle, Nalappatt Narayana Menon, an outstanding writer. However, she did no longer begin writing professionally until she got married and became a mother. She was working as the creative director of a marketing enterprise in Bangalore when she wrote her first book, a series of brief stories referred to as Satyr of the Subway, which she offered to Har Anand press. The book received her fellowship from the Virginia centre for creative Arts. Her second book was published by penguin India, was the first book via an Indian writer to be published by picador USA. Her books have been posted in numerous languages round the world. She lives in Bangalore. Among Nair's early industrial works were pieces she penned in the late 1990s for the Bangalore Monthly magazine (now called "080" Magazine), posted by Explicit in a column titled "The Economical Epicurean". There after followed her novel The Better Man (2000) which also has been published in Europe and USA. In 2002 brought out the collection of poems Malabar Mind in 2003 Where the Rain is born: Writings about Kerala, which she has edited.

E. Kamala Suraiyya 1934 - 2004 was an Indian writer who wrote in English and Malayalam, her native language. Her reputation in Kerala is based principally on her short stories and autobiography. She brazenly and honestly discussed and wrote about the sexual desires of Indian women, which made her an iconoclast of her generation. On thirty first May 2009, aged seventy five, she died at a hospital in Pune.

\section{Conclusion}

True literature is a vehicle of presenting the highest ideals and aspirations of mankind, as also a potent means of recycling and satisfying cultural values from generation to generation. Feminine responsiveness leads us to consider that literary texts can provide a real supportive of the ways in which society victimizes and works to the disadvantage of women. Literally, practice is an essential element of literature and it offers a special close into human experience, thus enabling us to sharpen our perception of social reality. Obviously, literary texts of men, as well as, women presume a meaning for the feminist. The feminist subjects images of womanhood, positive or negative, as portrayed by male and female writers to critical examination. 


\section{Acknowledgements}

I consider it my moral duty to pay my regards and thanks to the authors, librarians and publishers of all the books and papers which I have consulted during the preparation of the present paper.

\section{References}

[1] Agarwal, B. M. Post-Colonial Women Writers. Sublime Publications, 2012.

[2] Agarwal, Gujan and Pooja Kaushal. "Social Consciousness in Anita Nair's Ladies Coupe." The Criterion: An International Journal in English, vol. 6, no. 1, Feb. 2015, pp. 1-4.

[3] www.the-criterion.com/social-consciousness-in-anitanairs-ladies-coupe/

[4] Bhatnagar, Manmohan k. "Indian English Literature Its Rationale and A Critical Introduction." Indian Writing in English, edited by Bhatnagar, Atlantic Publishers and Distributors, vol. 1, 2001, pp. 1-6.

[5] Cherrian, Alice. "Feminine Sensibility in Anita Nair's Ladies Coupe and Mistress." A Feminist Psyche in World Women Novelists, edited by N. Shantha Naik, Sarup Book Publishers, 2010, pp. 15-26.

[6] Dhar, Debotri. "Radha's Revenge: Feminist Agency, Postcoloniality, and the Politics of Desire in Anita Nair's Mistress." Postcolonial Text, vol. 7, no. 4, Dec. 2008, pp. 1-16.

[7] www.postcolonial.org/index.php/pct/article/view/1535

[8] Jindal, Madhu. "Feminism and Literature: A Study of Anita Nair's Mistress." International Journal of Academic Research and Development, vol. 3, no. 1, Jan. 2018, pp. 1282-1285.

[9] www.academicsjournal.com/download/isio/3-1-428829.pdf

[10] Khatri, Chhote Lal. "Indian Novels in English: A Journey to the Nobel Height." Indian Novels in English, Book Enclave, 2004, pp. 4-5.

[11] The Introduction to Indian Writing In English Literature Essay

[12] www.ukessays.com/essays/english-literature/theintroduction-to-indian-writing-in-english-englishliterature-essay.php 